\title{
Autoimmune Global Amnesia as Manifestation of AMPAR Encephalitis and Neuropathologic Findings
}

Gerda Ricken, MSc, Tobias Zrzavy, MD, PhD, Stefan Macher, MD, Patrick Altmann, MD, PhD, Johannes Troger, MD, Kim Kristin Falk, MD, Andreas Kiefer, MD, Andreas Fichtenbaum, PhD, Goran Mitulovic, PhD, Helmut Kubista, PhD, Klaus-Peter Wandinger, MD, Paulus Rommer, MD, Thorsten Bartsch, MD, Thomas Berger, MD, MSc, Jörg Weber, MD, PhD, Frank Leypoldt, MD, PhD, * and Romana Höftberger, MD*

Neurol Neuroimmunol Neuroinflamm 2021;8:e1019. doi:10.1212/NXI.0000000000001019

\section{Abstract}

\section{Objective}

To report an unusual clinical phenotype of alpha-amino-3-hydroxy-5-methyl-4-isoxazolepropionic acid receptor (AMPAR) encephalitis and describe associated neuropathologic findings.

\section{Methods}

We retrospectively investigated 3 AMPAR encephalitis patients with autoimmune global hippocampal amnesia using comprehensive cognitive and neuropsychologic assessment, antibody testing by in-house tissue-based and cell-based assays, and neuropathologic analysis of brain autopsy tissue including histology and immunohistochemistry.

\section{Results}

Three patients presented with acute-to-subacute global amnesia without affection of cognitive performance, attention, concentration, or verbal function. None of the patients had epileptic seizures, change of behavior, personality changes, or psychiatric symptoms. The MRI was normal in 1 patient and showed increased fluid-attenuated inversion recovery/T2 signal in the hippocampus in the other 2 patients. Two patients showed complete remission after immunotherapy. The one patient who did not improve had an underlying adenocarcinoma of the lung and died 3.5 months after disease onset because of tumor progression. Neuropathologic analysis of the brain autopsy revealed unilateral hippocampal sclerosis accompanied by mild inflammatory infiltrates, predominantly composed of $\mathrm{T}$ lymphocytes, and decrease of AMPAR immunoreactivity.

\section{Conclusion}

AMPAR antibodies usually associate with limbic encephalitis but may also present with immune responsive, acute-to-subacute, isolated hippocampal dysfunction without overt inflammatory CSF or MRI changes.

\author{
Correspondence \\ Dr. Höftberger \\ romana.hoeftberger@ \\ meduniwien.ac.at
}




\section{Glossary}

AMPAR = alpha-amino-3-hydroxy-5-methyl-4-isoxazolepropionic acid receptor; abs $=$ antibodies; CBA = cell-based assays; FLAIR = fluid-attenuated inversion recovery; HIER = heat-induced epitope retrieval; TGA = transient global amnesia.

Autoantibodies to the GluA1 and/or GluA2 subunit of the alpha-amino-3-hydroxy-5-methyl-4-isoxazolepropionic acid receptor (AMPAR) were originally identified in patients with limbic encephalitis with prominent behavioral and psychiatric changes and epileptic seizures. ${ }^{1}$ Up to $64 \%$ have an underlying malignancy, most commonly thymoma, lung, or breast cancer. ${ }^{2-4}$ Subsequently, published studies expanded the spectrum of neurologic deficits to focal weakness, involuntary movements, autonomic dysfunction, upper motor neuron signs, apraxia, aphasia, sensory symptoms, or ataxia as additional symptoms apart from the limbic system. ${ }^{2,4}$ Recently, we identified AMPAR antibodies (abs) in the CSF of a 31-year-old patient, who presented with a clinical picture reminiscent of transient global amnesia without associated neurologic signs or overt inflammatory CSF or MRI changes and who readily responded to immunotherapy. This observation and 2 subsequent patients with similar phenotypes that came to our attention triggered this study. Our aim was to describe this unusual and possibly overlooked clinical presentation of AMPAR encephalitis, we tentatively dubbed autoimmune global hippocampal amnesia, and to present the associated neuropathologic findings in 1 patient who died because of an underlying malignancy.

\section{Methods}

Patient Identification, Serum, and CSF Samples All 3 patients were identified by screening accompanying clinical descriptions of cases whose serum/CSF samples were sent for diagnostic testing of antineuronal antibodies between 2016 and 2019 to participating laboratories in Lübeck, Kiel (Institute of Clinical Chemistry, University Hospital Schleswig-Holstein, Kiel/Lübeck) and Vienna (Division of Neuropathology and Neurochemistry, Department of Neurology, Medical University of Vienna). AMPAR abs were identified using an in-house tissuebased assay and in-house cell-based assays (CBA) transfected with the GluA1 and GluA2 subunit of the AMPAR, as described previously. ${ }^{2}$ All patients were personally examined by participating neurologists in Kiel, Vienna, or Klagenfurt.

\section{Standard Protocol Approvals, Registrations, and Patient Consents}

This study was approved by the Ethics Committee of the Medical University of Vienna (1,636/19 and 1,123/15), Lübeck (13-162), and Kiel (B337-13).

\section{Serum IgG Biotinylation and Competition Assay}

IgG was isolated from patients' or healthy control sera with protein A/G magnetic beads (88802, Thermo Fisher Scientific) and subsequently biotinylated with a sulfo-NHS- biotinylation kit (21425, Thermo Fisher Scientific) according to manufacturer's recommendations. These biotinylated human IgG samples were then used for competition assays to detect possible recognition of the same epitopes, as previously reported. ${ }^{5}$ Briefly, rat brain sections were blocked and incubated with serum samples overnight at $4^{\circ} \mathrm{C}$ (dilution $1 / 5$ ). After washing, the sections were then incubated with biotinylated human IgG (serial dilutions from $1 / 2$ to $1 / 10$ in $5 \%$ normal donkey serum) overnight at $4^{\circ} \mathrm{C}$, and the reactivity was developed with streptavidin-horseradish peroxidase solution followed by 3,3'-diaminobenzidin.

\section{Neuropathology}

Neuropathologic analysis was performed on formalin-fixed, paraffin-embedded tissue sections of human brain autopsy material. In total, 3-6 $\mu \mathrm{m}$ tissue sections were stained with hematoxylin and eosin, and Luxol fast blue and nuclear fast red staining. Immunohistochemistry was performed manually in a humidified chamber for complement C9 neoantigen (C9neo, polyclonal rabbit 1:2000, from Professor Paul Morgan, Cardiff, UK), GluA1 (AMPAR1, rabbit clone C3T 1:20; Merck/Millipore), GluA2/3 (AMPAR2/3, polyclonal rabbit 1:200; Merck/Millipore), Granzyme B (GranB, mouse clone GZB01 1:1,000; LabVision/Thermo Fisher Scientific), GRIK2 (kainate receptor 2, polyclonal rabbit 1:500; SigmaAldrich), and human Leukocyte antigen (HLA) (mouse clone HC10, 1:1,000, from Professor Hans Lassmann, Vienna, Austria), using an avidin-biotin-complex method. Enzymatic pretreatment with proteinase type 24 was used for C9neo staining; heat-induced epitope retrieval with ethylenediaminetetraacetic acid buffer $\mathrm{pH} 9$ was used for GluAl, Granzyme B, and HLA-I stainings; and heat-induced epitope retrieval with citrate buffer $\mathrm{pH} 6$ was used for GluA2/3 and GRIK2. Immunohistochemistry for the following primary antibodies was performed on an automated platform Autostainer Link 48 and Envision FLEX + detection kit (Dako/ Agilent) and used according to manufacturer's recommendations: alpha-synuclein (mouse clone 5G4 1:4,000; Analytik Jena), beta-amyloid (mouse clone 6F/3D 1:100; Dako/ Agilent), CD3 (rabbit clone SP7 1:100; NeoMarkers/ Thermo Fisher Scientific), CD4 (mouse clone 4B12 1:100; Dako/Agilent), CD8 (mouse clone C8/144B 1:100; Dako/ Agilent), CD20 (mouse clone L26 1:400; Dako/Agilent), CD68 (mouse clone KP1 1:5,000; Dako/Agilent), CD79a (mouse clone JCB117 1:100; Dako/Agilent), HLA-DR (mouse clone CR3/43 1:400; Dako/Agilent), IgG (polyclonal rabbit 1:16,000; Dako/Agilent), CD45/leucocyte common antigen (LCA; mouse clone $2 \mathrm{~B} 11+\mathrm{PD} 7 / 261$ : 2000; Dako/Agilent), Map2 (microtubule-associated protein2, mouse clone AP20 1:4,000; Merck/Millipore), pTDP-43 
(transactive response DNA-binding protein 43, phosphoSer409/410, mouse clone 11-9 1:20,000; Cosmo Bio), Tau (phospho-Ser202/Thr205, mouse clone AT8 1:200; Thermo Fisher Scientific), and TPPP/p25 (mouse clone 6C10 1: 2,000, from Professor Gabor Kovacs, Toronto, Canada). Heat-induced epitope retrieval (HIER) with target-retrieval solution low $\mathrm{pH}$ (Dako/Agilent) was used for pretreatment of alpha-synuclein, CD8, CD20, CD68, CD79a, HLA-DR, IgG, LCA, TDP-43, and TPPP/p25 staining, and target-retrieval solution high $\mathrm{pH}$ (Dako/Agilent) was used for pretreatment of CD3, CD4, and Map2 staining. Concentrated formic acid pretreatment for 1 minute was used for alpha-synuclein and pTDP-43 staining in addition to HIER. Approximately, 80\% formic acid (aqueous solution) for 1 hour was used for betaamyloid pretreatment. Tau staining needed no pretreatment. Image acquisition was performed on a NanoZoomer 2.0-HT digital slide scanner C9600 (Hamamatsu Photonics).

\section{Data Availability}

Anonymized data not published within this article will be made available by request from any qualified investigator.

\section{Results}

We identified 3 patients ( 1 woman and 2 men; mean age at symptom onset: 44 years; range 31-69 years) with a purely amnestic syndrome and high titers of AMPAR abs demonstrated with brain immunohistochemistry and in-house cellbased assays (table). Two patients had antibodies in serum and CSF (1 and 3), and 1 patient had antibodies only in CSF (2). The clinical presentation in all 3 patients was characterized by an acute-to-subacute onset of short episodes of poor recollection, evolving into complete global amnesia reminiscent of the clinical syndrome known as transient global amnesia (median time between first symptoms and full-fledged global amnesia 7.3 days, range 1-16 days). Comprehensive cognitive and neuropsychological assessment revealed severe and isolated deficits in visual short-term memory and auditory-verbal as well as figural long-term memory and thus hippocampal dysfunction. Cognitive performance, attention, and concentration; executive and verbal function; and visuoconstructive skills were unaffected. None of the patients had epileptic seizures, change of behavior, or psychiatric symptoms. While patient 1 had no visible changes on MRI imaging, patient 2 showed uni- and patient 3 bilateral increased fluid-attenuated inversion recovery (FLAIR)/T2 signal in the hippocampus. EEG and CSF analyses were unremarkable. Two patients showed substantial neurologic improvement after immunotherapy, 1 patient had a relapse 4 months after the initial event that fully responded to immunotherapy. One patient (3) had an adenocarcinoma of the lung and only partially responded to immunotherapy. She died 3.5 months after disease onset because of tumor progression.

The antibodies of 3 patients recognized different epitopes of the AMPAR, 2 labeled cells transfected with the GluA1 subunit, and 1 recognized cells transfected with the GluA2 subunit. Immune competition experiments demonstrated that preincubation of tissue with serum of patient 3 (recognizing GluA1 subunit) did not prevent the binding of a biotinylated AMPAR serum (also recognizing the GluA1 subunit) derived from a patient with classic symptoms of AMPAR encephalitis.

Neuropathologic analysis of the brain autopsy tissue of patient 3 revealed unilateral hippocampal sclerosis with subtotal loss of neurons in the CA1 and CA4 sectors of the left hippocampus (figure 1, A and B) accompanied by microglial activation (figure 1, C and $\mathrm{D}$ ); astrogliosis; and moderate meningeal, perivascular, and parenchymal inflammatory infiltrates. The parenchymal inflammation was mainly composed of CD3/CD8+ T cells (figure 1, E-F). HLA Class I antigen was upregulated in single neurons (figure $1 G$ ), some of them with apposed CD8+/GranB + cytotoxic T cells (figure 1, H and I). B cells and plasma cells were mainly restricted to the meninges (figure $1, \mathrm{~J}$ and $\mathrm{K}$ ). IgG deposits were detectable in preserved CA1 neurons, the subiculum, and occasionally in the isocortex. No deposits of complement C9neo were visible (data not shown). In addition, we found some perivascular inflammatory infiltrates in the basal ganglia, dentate nucleus, and brainstem. Few parenchymal infiltrates were visible in the formatio reticularis in the medulla oblongata. In addition, we found mild inflammatory infiltrates in the parietal and occipital meninges. The neurons in the prefrontal cortex and amygdala appeared well-preserved. No significant neurodegeneration-associated protein aggregates were detected; particularly, no pTDP-43, beta-amyloid, or alphasynuclein deposits were visible. We only identified single agerelated tau-positive neurofibrillary tangles, neuropil threads, and isolated perivascular and subpial astrocytes. To determine whether there was a decrease of expression of AMPAR, we stained the hippocampus sections of our patient and 7 agematched controls ( 3 men and 4 women) without hippocampal pathology and 3 patients ( 1 man and 2 women) with hippocampal sclerosis, with commercial anti-GluA1 (AMPAR1) and anti-GluA2/3 (AMPAR2/3) antibodies. Compared with controls (figure 2, A and B), the expression of AMPAR was substantially decreased in the patient's hippocampal formation (bilateral) (figure 2, C and D), whereas the number of synapses was not altered, as demonstrated with a commercial kainate receptor antibody (figure 2, E and F).

\section{Discussion}

We report 3 patients with AMPAR encephalitis whose clinical syndrome can be described as autoimmune global amnesia characterized by an acute-to-subacute, global amnestic syndrome without seizures, behavioral, or psychiatric abnormalities that lasted for up to 3 weeks and completely resolved after immunotherapy in the 2 cases without tumor. Acute isolated amnesia as clinical presentation of AMPAR encephalitis has previously been described in a 92-year-old woman, who remained stable after 6 cycles of IVIg. ${ }^{6}$ Although 
Table Summary of Patients' Characteristics

\begin{tabular}{|c|c|c|c|}
\hline Patients & 1 & 2 & 3 \\
\hline Age, sex & 31 , male & 32, male & 69 , female \\
\hline Clinical syndrome & Subacute global amnesia & Subacute global amnesia & Acute global amnesia \\
\hline First neurologic symptoms & $\begin{array}{l}\text { Episodic short-lasting memory } \\
\text { dysfunction }\end{array}$ & $\begin{array}{l}\text { Episodic memory dysfunction and } \\
\text { insomnia }\end{array}$ & Acute global amnesia \\
\hline $\begin{array}{l}\text { Time from onset to } \\
\text { global amnesia (d) }\end{array}$ & 16 & 5 & 1 \\
\hline MRI changes & Absent & $\begin{array}{l}\text { Unilateral mesiotemporal/ } \\
\text { hippocampal FLAIR alteration }\end{array}$ & $\begin{array}{l}\text { Bilateral hippocampal FLAIR/T2 } \\
\text { alteration }\end{array}$ \\
\hline CSF & Initially $6 \mathrm{WBC} / \mu \mathrm{L}$, no oligoclonal bands & $2 \mathrm{WBC} / \mu \mathrm{L}$, no oligoclonal bands & $4 \mathrm{WBC} / \mu \mathrm{L}$, no oligoclonal bands \\
\hline AMPAR abs titer & Serum: 1/800; CSF: 1/128 & Serum: negative; CSF: 1/64 & Serum: 1/1,600; CSF: $1 / 32$ \\
\hline Tumor & Not detected & Not detected & Adenocarcinoma lung \\
\hline Treatments & Iv steroids, rituximab & $\begin{array}{l}\text { Initially Iv steroids, PLEX; after } \\
3 \text { wk rituximab }\end{array}$ & Iv steroids, PLEX, chemotherapy \\
\hline Outcome and relapses & $\begin{array}{l}\text { Complete resolution after steroids, } \\
1 \text { relapse leading to rituximab, and } \\
\text { no further symptoms }\end{array}$ & $\begin{array}{l}\text { Response after steroids and } \\
\text { PLEX, complete resolution after } \\
\text { rituximab, } \\
\text { and no relapse }\end{array}$ & $\begin{array}{l}\text { Partial response after PLEX and died } \\
3.5 \text { mo after onset because of tumor } \\
\text { progression }\end{array}$ \\
\hline Follow-up & $56 \mathrm{mo}$ & $46 \mathrm{mo}$ & $3.5 \mathrm{mo}$ \\
\hline
\end{tabular}

Abbreviations: abs = antibodies; FLAIR/T2 = fluid-attenuated inversion recovery/T2-weighted imaging; PLEX = plasma exchange; WBC = white blood cells.

AMPARs are widely expressed in the brain, most patients with AMPAR encephalitis present with neurologic deficits that are restricted to the limbic system, including limbic encephalitis, seizures, behavioral, and memory deficits. Whether this is related to the density or composition of subunits of AMPARs or brain-region-dependent variations of compensatory mechanisms is unclear. ${ }^{7}$ AMPARs are heterotetrameric receptors composed of variable combinations of 4 subunits, GluA1-4. Our data from in-house CBAs and immunocompetition studies do not suggest that the isolated amnestic syndrome of our 3 patients is because of a specific receptor subunit and confirm the epitope diversity within the receptor that was described for AMPAR encephalitis. ${ }^{8}$

Amnestic syndrome refers to an impairment of memory and can be classified as anterograde or retrograde. It can be observed after trauma, bleeding, ischemia, or inflammation (viral or autoimmune, e.g., in limbic encephalitis associated with adenylate kinase 5 antibodies ${ }^{9}$ ) and may be a symptom of a psychiatric disorder (dissociative amnesia) or acute toxic

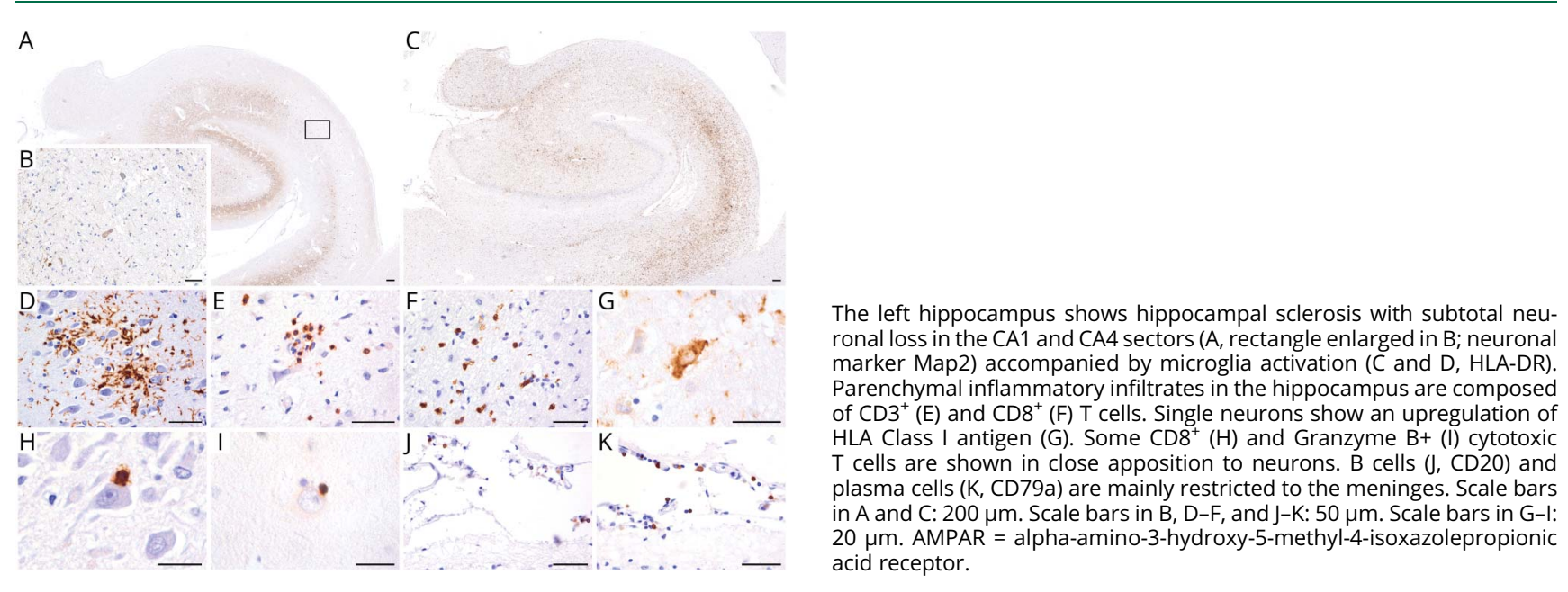


metabolic disorders. ${ }^{10,11}$ One of the most frequent forms is transient global amnesia (TGA) that is characterized by sudden onset of short-lasting ( $<24$ hours) anterograde amnesia in the absence of other neurologic deficits. ${ }^{12-14} \mathrm{An}$ impaired venous blood flow affecting hippocampal function through congestive ischemia has been proposed as a possible pathophysiologic mechanism. ${ }^{15}$ Shorter lasting episodes of global amnesia over minutes to few hours can occur as epileptic syndrome (transient epileptic amnesia). ${ }^{16}$ In contrast to TGA, the amnestic syndrome of our patients developed over a period of 1 to 16 days and lasted for several weeks to months although at the peak of disease patients were virtually indistinguishable from patients with TGA. In 1 patient (1) in light of normal MRI and CSF without clear inflammatory changes, a diagnosis of dissociative fugue was entertained. However, the MRI showing an increased FLAIR/T2 signal in the medial temporal lobes in the other 2 patients made the final diagnosis more straightforward.

The encoding, consolidation, and retrieval of mnemonic information is critically dependent on a large bidirectional network of brain areas that includes neocortical association regions, subcortical nuclei, and the medial temporal lobe, including the hippocampus. The hippocampus is a central node in the memory network and the site of pathology in many amnestic syndromes. Many intrahippocampal subnetworks are characterized by high densities of $\mathrm{GluAl} / 2$ and GluA2/3 receptors. ${ }^{17}$ A particularly vulnerable area is the CA1 sector, which is highly sensitive to hypoxia of diverse toxic or metabolic conditions, such as hypoglycemia or abuse of psychostimulant drugs. ${ }^{18}$ Neuropathologic investigation of the brain in our patient revealed unilateral hippocampal sclerosis affecting the CA1 and CA4 regions of the hippocampus. The contralateral hippocampus and other areas involved in memory, such as prefrontal cortex, cingulum, or thalamus, did not show significant neuronal loss or inflammation. However, we found IgG deposition and a decrease of AMPAR immunoreactivity that was most pronounced in the hippocampal formation on both sides and not associated with a decrease of synaptic density or complement deposition. These findings are in line with previous studies that demonstrated a decrease of synaptic clusters of AMPAR subunits through antibody-mediated internalization. ${ }^{1,19,20}$ Whether hippocampal sclerosis in our patient is a result of the pathogenic effects of the AMPAR antibodies on synaptic function in highly vulnerable regions or secondary to a T-cell-mediated mechanism possibly triggered by a tumor-associated breach of tolerance is unclear. A hypoxic damage of the hippocampal neurons was ruled out because the patient was not affected by hypoxicischemic events before death.

The cases reported here have important clinical implications: AMPAR encephalitis may present with an acute/subacute global amnestic syndrome, sometimes with normal MRI that is potentially reversible with immunotherapy. The pathologic substrate of this syndrome seems to be a predominant inflammatory involvement of the CA1 and CA4 regions of the hippocampus accompanied by a decrease of expression of AMPARs.

Figure 2 Decrease of AMPAR Density in Human Hippocampus In Vivo
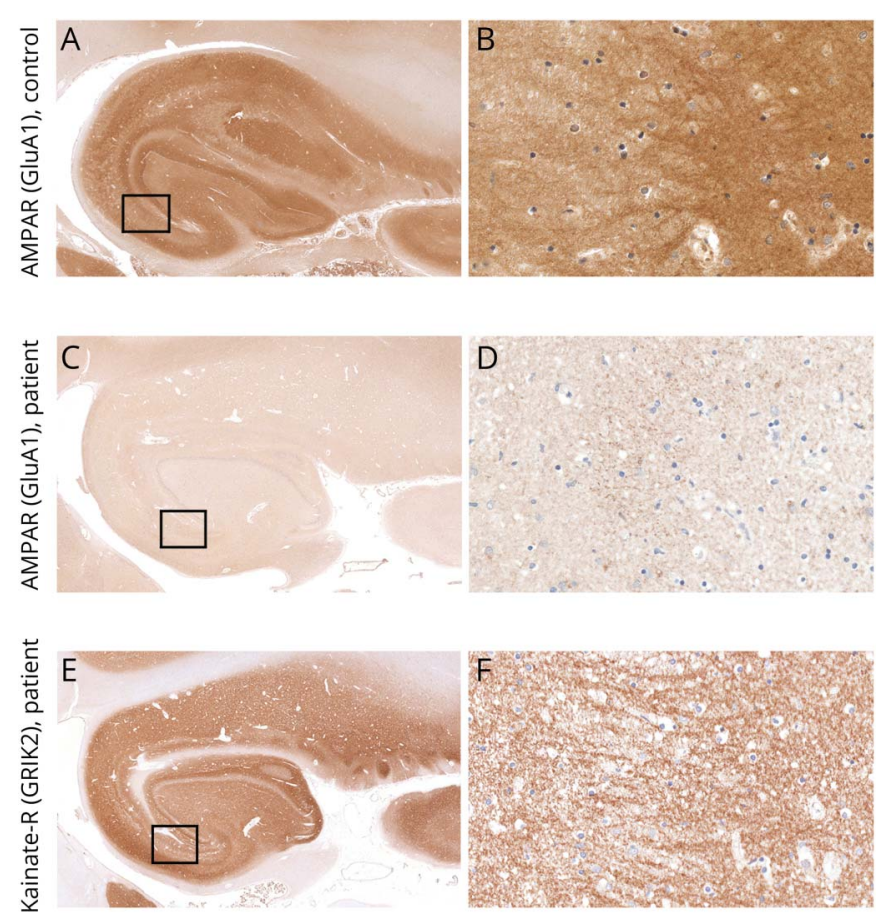

Compared with a control hippocampus (A, rectangle enlarged in B; GluA1), the hippocampus of the AMPAR encephalitis patient shows a significantly reduced AMPAR immunoreactivity ( $C$, rectangle enlarged in D; GluA1), whereas the synaptic density is not altered $(E$, rectangle enlarged in $F$; GRIK2). Scale bars in A, C, and E: $1 \mathrm{~mm}$. Scale bars in B, D, and F: $50 \mu \mathrm{m}$. $\mathrm{AMPAR}=$ alpha-amino-3-hydroxy-5-methyl-4-isoxazolepropionic acid receptor. 


\section{Acknowledgment}

The authors thank Prof. J. Dalmau (University of Barcelona, Spain) and Prof. E. Gelpi (Medical University of Vienna, Austria) for helpful comments, Prof. J. Dalmau for support in antibody testing, and Ulrike Köck (Medical University of Vienna, Austria) for her excellent technical support.

\section{Study funding}

This work was partly supported by grants from the "Jubiläumsfonds der Österreichischen Nationalbank," project 16919 (RH), Austrian Science Fund FWF, SYNABS (RH) and DOC 33-B27 (RH), and the German Ministry of Education and Research (BMBF, 01 GM1908A) (FL).

\section{Disclosure}

G. Ricken, T. Zrzavy, S. Macher, P. Altmann, J. Troger, K.K. Falk, A. Kiefer, A. Fichtenbaum, G. Mitulovic, H. Kubista, K.-P. Wandinger, P. Rommer, T. Bartsch, and J. Weber report no disclosures. T. Berger has participated in meetings sponsored by and received honoraria (lectures, advisory boards, and consultations) from pharmaceutical companies marketing treatments for MS: Allergan, Biogen, Biologix, Bionorica, Celgene, Eisei, MedDay, Merck, Novartis, Roche, Sanofi-Genzyme, Teva, and UCB. His institution has received financial support in the past 12 months by unrestricted research grants (Bayer, Biogen, Merck, Novartis, Roche, Sanofi-Genzyme, and Teva) and for participation in clinical trials in multiple sclerosis sponsored by Alexion, Bayer, Biogen, Merck, Novartis, Roche, Sanofi-Aventis, and Teva; Frank Leypoldt reports speakers honoraria from Grifols, Teva, Biogen, Roche, Alexion, Merck, Bayer, and Fresenius and advisory board memberships for Roche, Alexion, and Biogen outside of this work. He receives grants from the German Ministry of Education and Research (BMBF, 01 GM1908A) and the German Research Council (E-Rare Joint Transnational (ERA-Net) Transnational research call LE3064/2-1). He works for an academic institution that offers commercial antibody testing. R. Höftberger reports speaker's honoraria from Novartis and Biogen. The Medical University of Vienna (Austria; employer of Dr. Höftberger) receives payment for antibody assays and for antibody validation experiments organized by Euroimmun (Lübeck, Germany). Go to Neurology.org/nn for full disclosure forms.

\section{Publication History}

Received by Neurology: Neuroimmunology \& Neuroinflammation February 8, 2021. Accepted in final form March 23, 2021.

Appendix Authors

\begin{tabular}{lll}
\hline Name & Location & Contribution \\
\hline $\begin{array}{l}\text { Gerda Ricken, } \\
\text { MSc }\end{array}$ & $\begin{array}{l}\text { Medical University of } \\
\text { Vienna, Austria }\end{array}$ & $\begin{array}{l}\text { Conception and design, } \\
\text { acquisition of data, statistical } \\
\text { analysis, execution, } \\
\text { interpretation of data, and } \\
\text { critical review for } \\
\text { important intellectual } \\
\text { content }\end{array}$ \\
& \\
& \\
\hline
\end{tabular}

Appendix (continued)

\begin{tabular}{|c|c|c|}
\hline Name & Location & Contribution \\
\hline $\begin{array}{l}\text { Tobias Zrzavy, } \\
\text { MD, PhD }\end{array}$ & $\begin{array}{l}\text { Medical University of } \\
\text { Vienna, Austria }\end{array}$ & $\begin{array}{l}\text { Acquisition of data, execution, } \\
\text { and critical review for } \\
\text { important intellectual content }\end{array}$ \\
\hline $\begin{array}{l}\text { Stefan } \\
\text { Macher, MD }\end{array}$ & $\begin{array}{l}\text { Medical University of } \\
\text { Vienna, Austria }\end{array}$ & $\begin{array}{l}\text { Acquisition of data, } \\
\text { interpretation of data, and } \\
\text { critical review for important } \\
\text { intellectual content }\end{array}$ \\
\hline $\begin{array}{l}\text { Patrick } \\
\text { Altmann, MD, } \\
\text { PhD }\end{array}$ & $\begin{array}{l}\text { Medical University of } \\
\text { Vienna, Austria }\end{array}$ & $\begin{array}{l}\text { Acquisition of data, execution, } \\
\text { and critical review for } \\
\text { important intellectual content }\end{array}$ \\
\hline $\begin{array}{l}\text { Johannes } \\
\text { Troger, MD }\end{array}$ & $\begin{array}{l}\text { Klinikum Klagenfurt, } \\
\text { Austria }\end{array}$ & $\begin{array}{l}\text { Acquisition of data, execution, } \\
\text { and critical review for } \\
\text { important intellectual } \\
\text { content }\end{array}$ \\
\hline
\end{tabular}

\begin{tabular}{lll}
\hline Kim Kristin & University Hospital & $\begin{array}{l}\text { Acquisition of data, execution, } \\
\text { Falk, MD }\end{array}$ \\
$\begin{array}{ll}\text { Schleswig-Holstein, Kiel/ } \\
\text { Lübeck, Germany }\end{array}$ & $\begin{array}{l}\text { important intellectual } \\
\text { content }\end{array}$ \\
\hline
\end{tabular}

\begin{tabular}{lll}
\hline $\begin{array}{l}\text { Andreas } \\
\text { Kiefer, MD }\end{array}$ & $\begin{array}{l}\text { Klinikum Klagenfurt, } \\
\text { Austria }\end{array}$ & $\begin{array}{l}\text { Acquisition of data and critical } \\
\text { review for important } \\
\text { intellectual content }\end{array}$ \\
\hline $\begin{array}{l}\text { Andreas } \\
\text { Fichtenbaum, } \\
\text { PhD }\end{array}$ & $\begin{array}{l}\text { Medical University of } \\
\text { Vienna, Austria }\end{array}$ & $\begin{array}{l}\text { Acquisition of data, execution, } \\
\text { interpretation of data, and } \\
\text { critical review for important } \\
\text { intellectual content }\end{array}$ \\
\hline
\end{tabular}

\begin{tabular}{lll}
\hline $\begin{array}{l}\text { Goran } \\
\text { Mitulovic, } \\
\text { PhD }\end{array}$ & $\begin{array}{l}\text { Medical University of } \\
\text { Vienna, Austria }\end{array}$ & $\begin{array}{l}\text { Acquisition of data and critical } \\
\text { review for important } \\
\text { intellectual content }\end{array}$ \\
\hline $\begin{array}{l}\text { Helmut } \\
\text { Kubista, PhD }\end{array}$ & $\begin{array}{l}\text { Medical University of } \\
\text { Vienna, Austria }\end{array}$ & $\begin{array}{l}\text { Acquisition of data and } \\
\text { critical review for } \\
\text { important intellectual } \\
\text { content }\end{array}$
\end{tabular}

\begin{tabular}{lll}
\hline $\begin{array}{l}\text { Klaus-Peter } \\
\text { Wandinger, } \\
\text { MD }\end{array}$ & $\begin{array}{l}\text { University Hospital } \\
\text { Schleswig-Holstein, Kiel/ } \\
\text { Lübeck, Germany }\end{array}$ & $\begin{array}{l}\text { Interpretation of data and } \\
\text { critical review for } \\
\text { important intellectual } \\
\text { content }\end{array}$ \\
\hline $\begin{array}{l}\text { Paulus } \\
\text { Rommer, MD }\end{array}$ & $\begin{array}{l}\text { Medical University of } \\
\text { Vienna, Austria }\end{array}$ & $\begin{array}{l}\text { Interpretation of data and } \\
\text { critical review for important } \\
\text { intellectual content }\end{array}$
\end{tabular}

\begin{tabular}{lll}
\hline Thorsten & University Hospital & Interpretation of data and \\
Bartsch, MD & $\begin{array}{l}\text { Schleswig-Holstein, Kiel, } \\
\text { Germany }\end{array}$ & $\begin{array}{l}\text { critical review for } \\
\text { important intellectual } \\
\text { content }\end{array}$ \\
\end{tabular}

\begin{tabular}{lll}
\hline $\begin{array}{l}\text { Thomas } \\
\text { Berger, MD, } \\
\text { MSc }\end{array}$ & $\begin{array}{l}\text { Medical University of } \\
\text { Vienna, Austria }\end{array}$ & $\begin{array}{l}\text { Interpretation of data and } \\
\text { critical review for important } \\
\text { intellectual content }\end{array}$ \\
\hline $\begin{array}{l}\text { Jörg Weber, } \\
\text { MD, PhD }\end{array}$ & $\begin{array}{l}\text { Klinikum Klagenfurt, } \\
\text { Austria }\end{array}$ & $\begin{array}{l}\text { Acquisition of data, } \\
\text { interpretation of data, } \\
\text { and critical review for } \\
\text { important intellectual } \\
\text { content }\end{array}$ \\
\hline
\end{tabular}

\begin{tabular}{lll}
\hline $\begin{array}{l}\text { Frank } \\
\text { Leypoldt, MD, } \\
\text { PhD }\end{array}$ & $\begin{array}{l}\text { University Hospital } \\
\text { Schleswig-Holstein, Kiel/ } \\
\text { Lübeck, Germany }\end{array}$ & $\begin{array}{l}\text { Conception and design, } \\
\text { acquisition of data, execution, } \\
\text { interpretation of data, and } \\
\text { critical review for important } \\
\text { intellectual content }\end{array}$ \\
$\begin{array}{l}\text { Romana } \\
\text { Höftberger, } \\
\text { MD }\end{array}$ & Medical University of & $\begin{array}{l}\text { Conception and design, } \\
\text { acquisition of data, execution, } \\
\text { interpretation of data, and } \\
\text { critical review for important } \\
\text { intellectual content }\end{array}$ \\
\hline
\end{tabular}




\section{References}

1. Lai M, Hughes EG, Peng X, et al. AMPA receptor antibodies in limbic encephalitis alter synaptic receptor location. Ann Neurol. 2009;65(4):424-434.

2. Höftberger R, van Sonderen A, Leypoldt F, et al. Encephalitis and AMPA receptor antibodies: novel findings in a case series of 22 patients. Neurology. 2015;84(24): 2403-2412.

3. Dalmau J, Graus F. Antibody-mediated encephalitis. N Engl J Med. 2018;378(9): 840-851.

4. Laurido-Soto O, Brier MR, Simon LE, McCullough A, Bucelli RC, Day GS. Patient characteristics and outcome associations in AMPA receptor encephalitis. J Neurol. 2019;266(2):450-460.

5. Höftberger R, Sabater L, Velasco F, Ciordia R, Dalmau J, Graus F. Carbonic anhydrase-related protein VIII antibodies and paraneoplastic cerebellar degeneration. Neuropathol Appl Neurobiol. 2014;40(5):650-653.

6. Joubert B, Kerschen P, Zekeridou A, et al. Clinical spectrum of encephalitis associated with antibodies against the alpha-amino-3-hydroxy-5-methyl-4-isoxazolepropionic acid receptor: case series and review of the literature. JAMA Neurol. 2015;72(10): 1163-1169.

7. Palmer CL, Cotton L, Henley JM. The molecular pharmacology and cell biology of alpha-amino-3-hydroxy-5-methyl-4-isoxazolepropionic acid receptors. Pharmacol Rev. 2005;57(2):253-277.

8. Gleichman AJ, Panzer JA, Baumann BH, Dalmau J, Lynch DR. Antigenic and mechanistic characterization of anti-AMPA receptor encephalitis. Ann Clin Transl Neurol. 2014;1(3):180-189.

9. Do LD, Chanson E, Desestret V, et al. Characteristics in limbic encephalitis with antiadenylate kinase 5 autoantibodies. Neurology. 2017;88(6):514-524.
10. Alessandro L, Ricciardi M, Chaves H, Allegri RF. Acute amnestic syndromes. J Neurol Sci. 2020;413:116781.

11. Finke C, Prüss H, Heine J, et al. Evaluation of cognitive deficits and structural hippocampal damage in encephalitis with leucine-rich, glioma-inactivated 1 antibodies. JAMA Neurol. 2017;74(1):50-59.

12. Bartsch T, Deuschl G. Transient global amnesia: functional anatomy and clinical implications. Lancet Neurol. 2010;9(2):205-214.

13. Caplan LR. Transient global amnesia. In: Vinken PJ, Gruyn GW, Klawans HL, eds. Handbook of Clinical Neurology. Elsevier; 1985:205-218.

14. Hodges JR, Warlow CP. Syndromes of transient amnesia: towards a classification. A study of 153 cases. J Neurol Neurosurg Psychiatry. 1990;53(10):834-843.

15. Chung CP, Hsu HY, Chao AC, Sheng WY, Soong BW, Hu HH. Transient global amnesia: cerebral venous outflow impairment-insight from the abnormal flow patterns of the internal jugular vein. Ultrasound Med Biol. 2007; 33(11):1727-1735.

16. Bartsch T, Butler C. Transient amnesic syndromes. Nat Rev Neurol. 2013;9(2):86-97.

17. Sprengel R. Role of AMPA receptors in synaptic plasticity. Cell Tissue Res. 2006; 326(2):447-455.

18. Bartsch T, Wulff P. The hippocampus in aging and disease: from plasticity to vulnerability. Neuroscience. 2015;309:1-16.

19. Haselmann H, Mannara F, Werner C, et al. Human autoantibodies against the AMPA receptor subunit GluA2 induce receptor reorganization and memory dysfunction. Neuron. 2018;100(1):91-105.e9.

20. Peng X, Hughes EG, Moscato EH, Parsons TD, Dalmau J, Balice-Gordon RJ. Cellular plasticity induced by anti-alpha-amino-3-hydroxy-5-methyl-4-isoxazolepropionic acid (AMPA) receptor encephalitis antibodies. Ann Neurol. 2015;77(3):381-398. 


\title{
Neurology $^{\odot}$ \\ Neuroimmunology \& Neuroinflammation
}

\author{
Autoimmune Global Amnesia as Manifestation of AMPAR Encephalitis and \\ Neuropathologic Findings \\ Gerda Ricken, Tobias Zrzavy, Stefan Macher, et al. \\ Neurol Neuroimmunol Neuroinflamm 2021;8; \\ DOI 10.1212/NXI.0000000000001019
}

This information is current as of May 20, 2021

\section{Updated Information \& Services}

References

Subspecialty Collections

Permissions \& Licensing

\section{Reprints}

including high resolution figures, can be found at:

http://nn.neurology.org/content/8/4/e1019.full.html

This article cites 19 articles, 2 of which you can access for free at: http://nn.neurology.org/content/8/4/e1019.full.html\#\#ref-list-1

This article, along with others on similar topics, appears in the following collection(s):

Autoimmune diseases

http://nn.neurology.org//cgi/collection/autoimmune_diseases

Memory

http://nn.neurology.org//cgi/collection/memory

Information about reproducing this article in parts (figures,tables) or in its entirety can be found online at:

http://nn.neurology.org/misc/about.xhtml\#permissions

Information about ordering reprints can be found online: http://nn.neurology.org/misc/addir.xhtml\#reprintsus

Neurol Neuroimmunol Neuroinflamm is an official journal of the American Academy of Neurology.

Published since April 2014, it is an open-access, online-only, continuous publication journal. Copyright

Copyright (C) 2021 The Author(s). Published by Wolters Kluwer Health, Inc. on behalf of the American

Academy of Neurology.. All rights reserved. Online ISSN: 2332-7812.

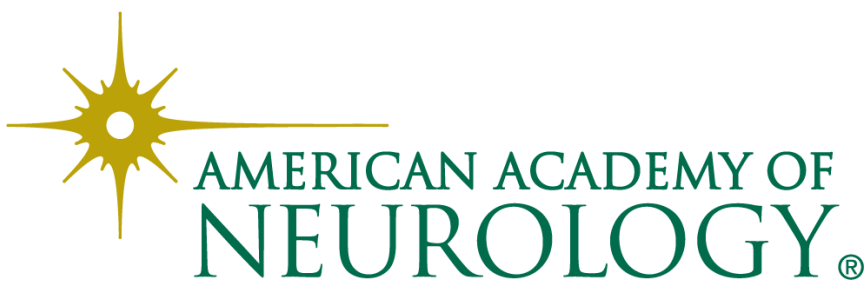

